\title{
ENGLISH LANGUAGE STUDENT TEACHERS' PEDAGOGICAL BELIEFS: SUSCEPTIBILITY TO CHANGE AND SOURCES OF CHANGE
}

ABSTRACT. Pedagogical beliefs comprise assumptions about different elements of education, and, hence, impact the entire pedagogical activity of the teacher. Relevant literature suggests it is vital to discover student teachers' beliefs, but it provides contradicting evidence regarding the effects that teacher preparation programs have on changing students' beliefs. This paper aims at discovering whether student teachers' beliefs alter in response to their attendance in different teacher-preparation courses, as well as the sources of that change. The paper is based on a mixed-model inquiry for whose purpose a Likert-scale questionnaire was composed and a semi-structured interview conducted. The sample included $11 \mathrm{EFL}$ postgraduate student teachers from Serbia. The gathered findings indicate a few statistically significant changes on the group level, while the results on the individual level reveal a variety of significant changes. Field practice was shown to have the greatest impact on changing student teachers' pre-existing beliefs, closely followed by a theoretical-practical course they attended, whereas the least impactful was a purely theoretical course.

KEYWORDS: student teachers' pedagogical beliefs; pre-existing beliefs; change of pre-existing beliefs; English language.

\footnotetext{
tatjana.glusac@gmail.com

vesna_pilipovic@yahoo.com

Рад је примљен 26. јануара 2019, а прихваћен за објављивање на састанку Редакције 3борника одржаном 18. марта 2019.
} 


\section{INTRODUCTION}

Pedagogical beliefs serve as the foundation for the teacher's entire pedagogical activity. They comprise a set of assumptions or propositions about the teaching profession, the teacher, the student, and the teaching and learning process. They impact the teacher's planning, decision making, attitude to work, relationship with students and colleagues, assessment practices, choice of content and material, and teaching techniques, among other elements. Those beliefs result from a variety of sources (personal experience as a learner, cultural background, working environment, etc.) and vary in relation to the stability of these sources.

Regardless of whether their beliefs are peripheral, and thus personal, implicit, complex, theoretically embraced (Phipps \& Borg, 2009 , p. 388) and hard to verbalize (Moscovici, 1984), or core, and hence dominant, culturally-laden, immutable, and easy to verbalize (Phipps \& Borg, 2009, p. 388), all pedagogical beliefs strongly influence teachers' entire pedagogical practice. These beliefs are generally in alignment, to a greater or lesser degree, with contemporary or desirable teaching principles and, respectively, either help or hamper a teacher and his/her students in achieving desired educational goals (Glušac, Milić \&Pilipović, 2017). It is still an unresolved question whether ineffective or incorrect teacher beliefs can be changed and how. Some literature suggests that student teachers' beliefs created prior to their formal education cannot be changed (Borg, 2005; Kagan, 1992; Peacock, 2001), whereas other authors (Busch, 2010; Cabaroglu \& Roberts, 2000; Clarke, 2008) claim that they are indeed susceptible to change. Along similar lines, there is some evidence suggesting that practicing teachers' beliefs are immutable (Hall, 2005; Williams \& Burden, 1997), even when they are faced with scientifically correct and grounded explanations (Pajares, 1992, p. 317), while some more recent research (Borg, 2011; Glušac, 2016) proves that they are flexible. One key to changing beliefs may be getting an opportunity to challenge them and discover they are unsatisfactory in practice (Guskey, 1986; Pajares, 1992). For this very reason, teacher preparation programs could be beneficial in enabling students to confront their own beliefs in practice at an early enough stage of their development, and thus challenge, and hopefully, change them. As beliefs are constituents of a teacher's professional identity (Beijaard, Meijer \& Verloop, 2004), it is of vital 
importance to deal with them properly as early as possible through teacher preparation programs.

\section{STUDENT TEACHER BELIEFS}

As observed by many researchers and theorists (e.g. Bangou, Fleming \& Goff-Kfouri, 2011; Borg, 2006; Borg, 2011), studies examining EFL student teachers' beliefs are still few and far apart and good quality research and concept definitions are currently not sufficiently available to enable the drawing of necessary conclusions that would inform the actions of teacher educators.

One thing, however, is certain - student teachers' pedagogical beliefs are well established by the time they get to college (Buchmann, 1987; Florio-Ruane \& Lensmire, 1990; Wilson, 1990). They are developed during the many years students spend at school and include views of the role of the teacher and student, the teaching process, etc.; they shape teachers' ideologies and even impact their relational behavior. Even though these early beliefs are mainly unarticulated for the vast majority of students, they are still brought into teacher preparation programs.

Research conducted mainly in the 1990 s and early 2000 s indicates that teacher preparation programs have little or no effect on the beliefs of their participating students (Gutierrez Almarza, 1996; Peacock, 2001; Pennington \& Urmston, 1998; Urmston, 2003). Some beliefs simply resist change and serve as filters of the information students are exposed to, owing to which they acquire only the information that complies with their existing beliefs (Kagan, 1992, p. 194). On the other hand, a growing body of modern-day research (Cabaroglu \& Roberts, 2000; Debreli, 2012; Graus \& Coppen, 2015; Kenyon, 2017; Kier \& Lee, 2017; Sheridan, 2016; Wall, 2016) suggests that many pre-existing beliefs may be shaken as new knowledge needs to be accommodated, and carefully and purposefully designed teacher preparation courses can help students in becoming good, competent practitioners with adequate belief systems. Relevant recent research suggests that such programs can alter students' views on teaching methods and techniques (e.g. Graus \& Coppen, 2015), their pedagogical beliefs (e.g. Sheridan, 2016), and even their professional identities (e.g. Kier and Lee, 2017). In their study that explored the effect of a teacher preparation program on student teachers' beliefs, Cabaroglu and Roberts (2000, p. 393) demonstrated 
that a change in beliefs can take different forms - it can be realized as awareness, elaboration/polishing, addition, reordering, relabeling, linking up, disagreement, or reversal. Not every student belief, however, is susceptible to change, and such resistance comes in the form of the consolidation/confirmation of existing beliefs, posed change, and the absence of change.

It is of utmost importance for teachers, and even more so for student teachers, to become aware of their beliefs at some point of their careers as teachers for two primary reasons - they need to be aware that their beliefs heavily influence their practice and that all those beliefs that do not serve them well should be replaced or discarded. The sooner teachers become aware that they hold a belief that is of no use to them or their students, the better. Therefore, those working with student teachers should make these students confront their own beliefs as part of the course curriculum they teach (Cabaroglu \& Roberts, 2000, p. 399; Wall, 2016, p. 375), as any attempt to change their beliefs once they become practicing teachers may pose a threat to their personality (Glušac, Milić, \& Pilipović, 2017); many equate a change of beliefs with personal change (Yero, 2002). Moreover, disposing of any incorrect beliefs among students would lead to their more successful professional preparation. As pointed out by Kagan (cited in Valcke, Sang, Rots \& Hermans, 2010, p. 625), "Student teachers who fail to reconstruct their images of self as teachers appropriately may encounter frustrations sufficiently severe to terminate their teaching career before they really had a chance to begin".

Drawing on the model of the pedagogy of realistic teacher education, Valcke, Sang, Rots and Hermans (2010, pp. 625-626) propose several activities an effective teacher preparation program should encompass: (1) engaging student teachers in as much actual practice as possible; (2) giving candidate teachers ample opportunities to share and discuss instructional practices with peers; (3) stimulating discussions on the adoption of teaching and learning approaches; (4) confronting students with dissonance; (5) providing early apprenticeship opportunities; (6) asking students to reconsider beliefs they hold through value clarification; (7) engaging students in case studies. These activities are believed to help shape, reshape, rethink, confirm, or discard the beliefs student teachers bring into their teacher preparation courses. In the same vein, Wall (2016, pp. 375-377) advocates for enabling student teachers to learn to think, know, act, and feel like a teacher through a myriad of reflective, col- 
laborative, individual, theoretical, and practical activities. Many theorists and researchers (e.g. Debreli, 2012; Doyle, 1997; Sheridan, 2016; Valcke, Sang, Rots \& Hermans, 2010) assert that field work is a key ingredient of good quality teacher education. In addition, Sheridan $(2016$, p. 4) proposes that an influential teacher education program is authentic, is linked to relevant coursework, offers exposure to various classes, and is supported by experienced teachers. Furthermore, she claims that central to teacher education is also the teacher educators' understanding of how students learn to teach and how they implement their views on teaching. Cabaroglu and Roberts (2000, p. 389) claim that an effective teacher preparation program that is capable of changing students' pedagogical beliefs is based on experiential learning and reflective practice. Moreover, they suggest that students need to be obligated to confront their pre-existing beliefs as early as possible, as well as to be provided with numerous self-regulated learning opportunities (Cabaroglu \& Roberts, 2000, p. 399).

Modern-day research findings on the malleability of student teachers' beliefs are rather encouraging in that they enable teacher educators to impact those beliefs by designing courses that should help students discard incorrect beliefs and develop those that should help them grow into good, competent practitioners in need today.

The aim of this paper is twofold: first, it is the authors' intention to discover whether beliefs change in response to students' exposure to theoretical content and practical experience; second, the authors aim to discover the variables that lead to belief change.

\section{RESEARCH}

\section{TIME AND PARTICIPANTS}

As the overarching aim of the study was to explore whether any changes in beliefs occurred due to students' participation in two teacher preparation courses, the duration of the research was one semester (February - June 2017).

The participants in the study were 11 fourth-year students of English (four males and seven females) attending a private faculty in Serbia. They ranged in age from 22 to 25 years. The mean value of their success in their studies up to that point was 8.4 (10 being the 
maximum) and at the time the research was conducted they had been learning English for 12.4 years on average. None of the students then possessed experience in teaching a class of students, but some had worked as private tutors.

\section{CONTEXT}

The participants were first acquainted with the principles of EFL teaching methodology in their third year of study. During the semester when the research was carried out, they had two simultaneous teaching-related courses: Theories of Second Language Acquisition and Teaching Techniques. The aim of the former is to familiarize students with factors influencing second/foreign language learning mainly through providing them with information related to different theoretical and empirical works. The course is highly theoretical in nature and presupposes no field work. However, it calls for students' participation in discussions.

The second course presupposes learning about teaching techniques suitable for students of different ages and with different needs, as well as about those appropriate for teaching different aspects of language. After laying important theoretical foundations, the course enables students to get practical experience in planning lessons, do micro-teaching, observe practicing teachers, and engage in real classroom teaching. At the end of their field work, the students were required to give a full 45-minute lesson while observed by their teacher-mentor and a university teacher.

\section{DATA SOURCES AND COLLECTION}

This study combines qualitative and quantitative research techniques. Following Valcke Sang, Rots, and Hermans's (2010, p. 624) suggestion regarding the most effective techniques for investigating teacher beliefs, a questionnaire was employed along with a semi-structured interview.

Immediately before the courses began, the students were asked to complete a Likert-type questionnaire. The questionnaire included 27 statements related to the issues that would be dealt with within the two teacher preparation courses, such as the role of the teacher and student, types and effects of teaching techniques, classroom management, assessment practice, etc.

During the semester, the students participated in various discussions, created their own lesson plans, carried out micro-teaching, 
and both gave and received feedback from peers related to the lesson they presented to them. In May 2017, the students were expected to give an examination lesson to a class of students in the state school in which they had previously conducted their observations.

At the end of the semester (on May 30, 2017), the students were asked to complete the same questionnaire they had completed at the beginning of the semester, as it was the researchers' intention to explore whether any change had occurred as a result of their exposure to the teacher preparation courses.

As the questionnaires were not done anonymously, the researchers paired each participant's two questionnaires for comparison and marked those questions for which the answers had revealed a change in belief. Four weeks after they completed the second questionnaire (on June 28, 2017), the first author conducted a semi-structured interview with the students, using a scripted protocol aimed at revealing the causes that initiated changes in beliefs. The researcher followed a topical trajectory by asking the same main questions (e.g., Can you recall what triggered the change of this belief during the semester?, Do you think that the teacher preparation courses helped you change some of your beliefs?, etc.), but the interviewer was also permitted to stray from the planned questions by asking probes to prompt students' recollection and discussion. The interview presupposed that the researcher would show the interviewee his/her two questionnaires, point to questions that signaled a change in belief and ask the student to explain why the change had occurred and what it had been prompted by.

The researchers acknowledge a certain dose of subjectivity as the first author was simultaneously a researcher and teacher educator to the participants.

\section{DATA ANALYSIS}

To achieve the stated objectives, the study included analysis at both the group and individual level.

As the participants were asked to complete the same questionnaire twice, a paired-samples t-test using SPSS15 was performed to find out whether any statistically significant differences were evident between the two groups of responses.

To analyze the obtained data on the individual level, the two questionnaires for each participant were manually compared and those answers that were characterized by a change of response were marked. In deciding whether an entry belief had changed, the fol- 
lowing principles were used as guidance: answer options 1 and 2, as well as 4 and 5, were considered to represent the same category disagreement or agreement, respectively. Hence, if in the initial test a student endorsed 1 and in the second 2, no change was considered to have occurred in his/her belief. Answer 3 represented a separate category of response - uncertainty about the trustworthiness of the statement; hence, if a student in the initial test endorsed any answer from the other two categories and in the second chose option 3, his/ her belief was considered to have changed, resulting in uncertainty at the time the second questionnaire was administered. The same principle was applied if the chosen number option indicating the level of agreement had decreased/increased in the second questionnaire.

Finally, the answers the students had given during interviews were analyzed using an inductive approach. It required multiple readings of transcripts, coding, clustering, defining codes, and sorting extracted key phrases into established categories.

\section{RESEARCH FINDINGS AND DISCUSSION}

\section{RESULTS OF QUESTIONNAIRES}

A paired-samples t-test was performed to identify whether any changes occurred in students' beliefs owing to their exposure to theoretical and practical courses they attended in between the two questionnaires. Of the 27 questions, there are four with statistically significant answers (questions $1(t=-3.36, d f=10, p=0.01), 3(t=$ 2.16, $d f=10, p=0.05), 4(t=2.63, d f=10, p=0.03)$ and $8(t=-2.32, d f=$ $10, p=0.04))$. These questions probed students' beliefs about lesson planning (questions 1 and 3), the role of the course book (question 4 ), and teaching grammar (question 8) (for the text of the corresponding statements please refer to Table 2). The theoretical-practical course the students attended in between the two questionnaires dealt extensively with lesson planning. The students were first acquainted with the principles of planning a lesson, then they were given samples of lesson plans to analyze, after which they were expected to design two lesson plans on their own. Both the theoretical considerations and practical work on lesson planning seem to have impacted their beliefs regarding this issue. The results of the part of the interview relating to lesson planning 
(see Table 2, questions 1, 2, and 3) reveal that this course made a greater impact on students' belief than did field work or the combination of the two sources.

Moreover, when working on their own lesson plans, students appeared to rely heavily on the course book as the major source of information and the only teaching resource. Such a finding was followed by intensive discussions about the role of the course book in language teaching and it was supported by numerous examples of when and how a course book should be used and substituted by other teaching materials. Such discussions and examples seem to have impacted students' views of the course book significantly. Again, the impact of the course, i.e. of how the issue was dealt with in the course, affected the change of this belief more than field work itself (see Table 2, statement 4).

Along the same lines, in planning their lessons, students displayed a tendency to employ grammar drills to a large extent. Such an observation was followed by discussions and video clips featuring teachers covering different grammatical aspects in more productive and interesting ways. However, the results of the interview (see Table 2, statement 8) show that field work was the factor that stimulated students to change their pre-existing beliefs regarding this issue, not the course.

Considered at the group level, the other 23 beliefs remained unchanged, according to statistical measures. Such a finding corroborates the results obtained by Cabaroglu and Roberts (2000, p. 389 ), which indicate that group-level statistics might give an impression that no change occurs, while at the individual level, significant changes might transpire. For this reason, we compared individual results on both questionnaires and, if a change in response was noted, the student was interviewed.

\section{RESULTS OF THE INTERVIEW}

The analysis of individual student's results from the questionnaires reveals a significant change of at least a few beliefs for each respondent, the minimum number being 5 and the maximum 24 . The results show that there is not a single student whose entire scope of entry beliefs remained intact at the end of the semester (see Table 1). This can only indicate that teacher preparation courses do have the capacity to impact student teachers' entry beliefs. Moreover, the group results show that beliefs about all 27 statements changed at least once on the individual level. However, the 
individual level analysis shows that some student beliefs about certain pedagogical issues remained nearly intact (see Table 2, statements 17, 19, 20 and 27) despite their attendance in teacher preparation programs. As noted by Cabaroglu and Roberts (2000, p. 93), the courses that these students attended may have only consolidated their beliefs or those beliefs may have been so deeply rooted already that could not be changed, even when students were given an opportunity to observe or experience teaching in a real classroom.

As is evident in Table 1, when asked about the source of the change of their beliefs, the respondents separated field work from the rest of the course. As noted before, field work is indeed part of the Teaching Techniques course, yet the students referred to it during the interview as a separate activity, likely because of its contrasting nature in comparison to a typical university course; it gives them an opportunity to learn in a different context and do practical work in a real classroom.

The results obtained through the interview (see Table 1) reveal that what influenced changes in beliefs to the greatest extent was field work (53 beliefs). Such a finding corroborates the results of similar research studies (Debreli, 2012, p. 372; Doyle, 1997, cited in Clark-Goff, 2008, pp. 55-56; Valcke, Sang, Rots \& Hermans, 2010, p. $625)$ showing that experiential and reflective learning that gives students ample opportunities to observe, give and get feedback, discuss, and try out elements they encounter in their university courses is indeed most effective.

The results also reveal that the second most influential factor was one of the two courses the students attended, Teaching Techniques, which is both theoretical and practical in nature ( 45 beliefs were reported to have changed owing to the course). This finding reveals that student teachers' beliefs can be heavily influenced by the opportunity to be acquainted with different teaching methodology principles through theory that is supported by numerous real classroom examples, video clips, discussions, lesson plan samples, discussions, individual work, and peer and teacher feedback. Such a finding - that a teacher preparation course that includes enhanced learning through various classroom experiences - is consistent with the findings of other researchers (e.g. Clark-Goff, 2008, p. 146). Furthermore, the results show that the course which was highly theoretical in nature - Theories of Second Language Acquisition was not particularly influential on its own (4 reported changed 
beliefs), nor was it in combination with either field work (2 reported changed beliefs) or Teaching Techniques (1 reported changed belief). However, the student who had the greatest number of her beliefs changed (S7) was influenced by a myriad of factors, but the Teaching Techniques course appears to have had the greatest impact, as it was indicated as a source for the changing of 17 of her beliefs.

In summation, the results presented in Table 1 indicate that what triggers change is highly individual, as well as that both courses and practical work are effective for some students.

\begin{tabular}{|c|c|c|}
\hline STUDENT & $\begin{array}{c}\text { NUMBER OF } \\
\text { CHANGED BELIEFS }\end{array}$ & SOURCES OF CHANGE OF BELIEFS \\
\hline 1 & 5 & $\begin{array}{l}\text { Teaching techniques (2) } \\
\text { Field work (2) } \\
\text { Teaching techniques and field work (1) }\end{array}$ \\
\hline 2 & 13 & $\begin{array}{l}\text { Teaching techniques (3) } \\
\text { Field work (9) } \\
\text { Theories of language acquisition (1) }\end{array}$ \\
\hline 3 & 7 & $\begin{array}{l}\text { Teaching techniques (3) } \\
\text { Field work (4) }\end{array}$ \\
\hline 4 & 10 & $\begin{array}{l}\text { Field work (6) } \\
\text { Teaching techniques and field work (3) } \\
\text { Theories of language acquisition and field work (1) }\end{array}$ \\
\hline 5 & 11 & $\begin{array}{l}\text { Teaching techniques (4) } \\
\text { Field work (5) } \\
\text { Teaching techniques and field work (2) }\end{array}$ \\
\hline 6 & 6 & Field work (6) \\
\hline 7 & 24 & $\begin{array}{l}\text { Teaching techniques (17) } \\
\text { Field work (2) } \\
\text { Teaching techniques and field work (4) } \\
\text { Theories of language acquisition (1) }\end{array}$ \\
\hline 8 & 16 & $\begin{array}{l}\text { Teaching techniques (5) } \\
\text { Field work (6) } \\
\text { Teaching techniques and field work (2) } \\
\text { Theories of language acquisition (1) } \\
\text { Teaching techniques and Theories of language acquisition (1) } \\
\text { Theories of language acquisition and field work (1) }\end{array}$ \\
\hline
\end{tabular}

TABLE 1: NUMBER AND REPORTED SOURCE OF CHANGED BELIEFS 


\begin{tabular}{||c|c|l||}
\hline 9 & 8 & $\begin{array}{l}\text { Teaching techniques (3) } \\
\text { Field work (4) } \\
\text { Theories of language acquisition (1) }\end{array}$ \\
\hline 10 & 9 & $\begin{array}{l}\text { Teaching techniques (6) } \\
\text { Field work (2) } \\
\text { Teaching techniques and field work (1) }\end{array}$ \\
\hline 11 & 9 & $\begin{array}{l}\text { Teaching techniques (2) } \\
\text { Field work (7) }\end{array}$ \\
\hline
\end{tabular}

TABLE 1: NUMBER AND REPORTED SOURCE OF CHANGED BELIEFS

The results showing the change of beliefs regarding the 27 questions from the questionnaire (Table 2) reveal that there is not a single statement about which at least one student did not change their belief. However, there are four beliefs (statements 17, 19, 20, and 27) that remained relatively unchanged, as only one student (S7) was indicated to have altered his/her beliefs regarding these aspects of teaching. Again, the results indicate that what triggers the change of one's particular belief is highly individual. For some students, observing or doing practical work was the most influential, whereas for others a course they attended was effective enough to initiate change.

When the students were asked to recall the change of a specific belief, all of them gave detailed accounts of classroom situations that conflicted with the belief they had possessed up to that moment. They all also reported that it was the effect of a certain technique or strategy a teacher applied, or a change in students' behavior or knowledge, that had triggered the change in their beliefs. In other words, any educational decision that has a positive outcome seems to trigger the evaluation of pre-service teachers' pedagogical beliefs.

\begin{tabular}{||l|l|l||}
\hline \multicolumn{1}{|c|}{ STATEMENT } & $\begin{array}{l}\text { NUMBER OF STUDENTS } \\
\text { WHO CHANGED THIS } \\
\text { BELIEF }\end{array}$ & \multicolumn{1}{|c|}{ SOURCE OF CHANGE } \\
\hline $\begin{array}{l}\text { 1. It is not necessary to plan } \\
\text { every lesson in detail. A teacher } \\
\text { can decide about some of its ele- } \\
\text { ments during the class. }\end{array}$ & $\begin{array}{l}\text { S1,S2, S4, S5, S7, S8, } \\
\text { S10, S11 }\end{array}$ & $\begin{array}{l}\text { Teaching techniques (6) } \\
\text { Teaching techniques and field } \\
\text { work (2) }\end{array}$ \\
\hline
\end{tabular}

TABLE 2: NUMBER OF STUDENTS WHO CHANGED A PARTICULAR BELIEF AND SOURCES OF CHANGE 


\begin{tabular}{|c|c|c|}
\hline $\begin{array}{l}\text { 2. It is acceptable for a teacher to } \\
\text { stray away from the lesson plan } \\
\text { to a lesser or greater degree } \\
\text { from time to time. }\end{array}$ & S1, S3, S5, S7, S8 & Teaching techniques (5) \\
\hline $\begin{array}{l}\text { 3. The lesson always needs to } \\
\text { have the same structure so that } \\
\text { students can foresee what each } \\
\text { stage of the lesson will be like. }\end{array}$ & $\begin{array}{l}\text { S2, S3, S4, S5, S6, S7, } \\
\text { S8, S9 } \\
\\
\text { Total: } 8\end{array}$ & $\begin{array}{l}\text { Teaching techniques (3) } \\
\text { Field work (2) } \\
\text { Teaching techniques and field } \\
\text { work (3) }\end{array}$ \\
\hline $\begin{array}{l}\text { 4. The course book is the major } \\
\text { resource material and the teach- } \\
\text { er needs to follow it strictly. }\end{array}$ & $\begin{array}{l}\begin{array}{l}\text { S2, S3, S4, S5, S7, S8, } \\
\text { S10 } \\
\text { Total: } 7\end{array} \\
\end{array}$ & $\begin{array}{l}\text { Teaching techniques (5) } \\
\text { Teaching techniques and field } \\
\text { work (2) }\end{array}$ \\
\hline $\begin{array}{l}\text { 5. The most important aspect of } \\
\text { language is grammar and it } \\
\text { should be given most attention. }\end{array}$ & $\begin{array}{r}\text { S4, S7, S8, S9, S10 } \\
\text { Total: } 5\end{array}$ & $\begin{array}{l}\text { Field work (3) } \\
\text { Teaching techniques and field } \\
\text { work (2) }\end{array}$ \\
\hline $\begin{array}{l}\text { 6. It is best to ask students to do } \\
\text { writing assignments at home. }\end{array}$ & S7, S8, S9, S10 & $\begin{array}{l}\text { Teaching techniques (1) } \\
\text { Field work (2) } \\
\text { Teaching techniques and field } \\
\text { work (1) }\end{array}$ \\
\hline $\begin{array}{l}\text { 7. It is possible to organize } \\
\text { speaking activities in large } \\
\text { classes. }\end{array}$ & $\begin{array}{l}\begin{array}{l}\text { S3, S4, S5, S6, S7, S8, } \\
\text { S11 } \\
\text { Total: } 7\end{array} \\
\end{array}$ & Field work (7) \\
\hline $\begin{array}{l}\text { 8. Grammar is best practiced } \\
\text { through drills. }\end{array}$ & $\begin{array}{l}\begin{array}{l}\text { S1, S4, S5, S6, S7, S9, } \\
\text { S10, S11 } \\
\text { Total: } 8\end{array}\end{array}$ & Field work (8) \\
\hline $\begin{array}{l}\text { 9. Reading comprehension is im- } \\
\text { proved by oral translation of the } \\
\text { text. }\end{array}$ & $\mathrm{S} 2, \mathrm{~S} 4, \mathrm{~S} 8, \mathrm{~S} 9, \mathrm{~S} 10, \mathrm{~S} 11$ & $\begin{array}{l}\text { Teaching techniques (2) } \\
\text { Field work (3) } \\
\text { Teaching techniques and field } \\
\text { work (1) }\end{array}$ \\
\hline $\begin{array}{l}\text { 10. Pronunciation is paramount } \\
\text { in learning a foreign language. }\end{array}$ & $\mathrm{S} 2, \mathrm{~S} 4, \mathrm{~S} 7, \mathrm{~S} 8, \mathrm{~S} 10, \mathrm{~S} 11$ & $\begin{array}{l}\text { Teaching techniques ( } 3 \text { ) } \\
\text { Theories of language acquisition } \\
(2) \\
\text { Theories of language acquisition } \\
\text { and field work (1) }\end{array}$ \\
\hline $\begin{array}{l}\text { 11. The main aim of foreign lan- } \\
\text { guage learning is improving } \\
\text { one's ability to communicate, } \\
\text { orally or in a written form. }\end{array}$ & Total: 2 & $\begin{array}{l}\text { Teaching techniques (1) } \\
\text { Field work (1) }\end{array}$ \\
\hline $\begin{array}{l}\text { 12. Homework is very helpful in } \\
\text { improving knowledge. }\end{array}$ & $\mathrm{S} 1, \mathrm{~S} 2, \mathrm{~S} 7$ & $\begin{array}{l}\text { Teaching techniques (1) } \\
\text { Field work (2) }\end{array}$ \\
\hline
\end{tabular}

TABLE 2: NUMBER OF STUDENTS WHO CHANGED A PARTICULAR BELIEF AND SOURCES OF CHANGE 


\begin{tabular}{|c|c|c|}
\hline $\begin{array}{l}\text { 13. It is not possible to organize } \\
\text { interesting lessons without the } \\
\text { use of technology. }\end{array}$ & $\mathrm{S} 4, \mathrm{~S} 5, \mathrm{~S} 8, \mathrm{~S} 9$ & Field work (4) \\
\hline $\begin{array}{l}\text { 14. The teacher's role is to trans- } \\
\text { fer knowledge. }\end{array}$ & $\begin{array}{r}\text { S2, S3, S7, S11 } \\
\text { Total: } 4\end{array}$ & $\begin{array}{l}\text { Teaching techniques (1) } \\
\text { Field work ( } 3 \text { ) }\end{array}$ \\
\hline $\begin{array}{l}\text { 15. The teacher should guide } \\
\text { and support students to learn on } \\
\text { their own. }\end{array}$ & Total: 2 & $\begin{array}{l}\text { Teaching techniques (1) } \\
\text { Field work (1) }\end{array}$ \\
\hline $\begin{array}{l}\text { 16. Every student is able to learn } \\
\text { a foreign language. }\end{array}$ & $\mathrm{S} 1, \mathrm{~S} 2, \mathrm{~S} 3, \mathrm{~S} 7, \mathrm{~S} 8$ & $\begin{array}{l}\text { Field work (2) } \\
\text { Theories of language acquisition } \\
(1) \\
\text { Theories of language acquisition } \\
\text { and field work (2) }\end{array}$ \\
\hline $\begin{array}{l}\text { 17. It is important to know one's } \\
\text { students for ensuring success in } \\
\text { learning. }\end{array}$ & Total: 1 & Teaching techniques (1) \\
\hline $\begin{array}{l}\text { 18. Punishing students is the } \\
\text { best way to discipline a class. }\end{array}$ & $\begin{array}{rr}\text { S2, S6, S7, S8 } & \\
& \text { Total: } 4\end{array}$ & $\begin{array}{l}\text { Teaching techniques (1) } \\
\text { Field work (3) }\end{array}$ \\
\hline $\begin{array}{l}\text { 19. It is important the teacher } \\
\text { ensure a comfortable, pleasant } \\
\text { and non-threatening working } \\
\text { atmosphere. }\end{array}$ & Total: 1 & Teaching techniques (1) \\
\hline $\begin{array}{l}\text { 20. Learning should be a pleas- } \\
\text { ant experience, not an imposed } \\
\text { activity. }\end{array}$ & Total: 1 & Teaching techniques (1) \\
\hline $\begin{array}{l}\text { 21. Students should learn in ac- } \\
\text { cordance with their capabilities. }\end{array}$ & $\begin{array}{r}\text { S2, S5, S7, S8, S10, S11 } \\
\text { Total: } 6\end{array}$ & $\begin{array}{l}\text { Teaching techniques (2) } \\
\text { Field work (3) } \\
\text { Teaching techniques and Theo- } \\
\text { ries of language acquisition (1) }\end{array}$ \\
\hline $\begin{array}{l}\text { 22. Learning about a foreign cul- } \\
\text { ture is an important segment of } \\
\text { learning a foreign language. }\end{array}$ & Total: 2 & $\begin{array}{l}\text { Teaching techniques (1) } \\
\text { Field work (1) }\end{array}$ \\
\hline $\begin{array}{l}\text { 23. A teacher should employ dif- } \\
\text { ferent work formats during a } \\
\text { single class. }\end{array}$ & Total: 2 & $\begin{array}{l}\text { Teaching techniques (1) } \\
\text { Field work (1) }\end{array}$ \\
\hline $\begin{array}{l}\text { 24. The best way to assess stu- } \\
\text { dents' knowledge is through a } \\
\text { test. }\end{array}$ & $\begin{array}{l}\text { S3, S4, S5, S6, S7, S9, } \\
\text { S11 } \\
\text { Total: } 7\end{array}$ & $\begin{array}{l}\text { Teaching techniques (2) } \\
\text { Field work (5) }\end{array}$ \\
\hline
\end{tabular}

TABLE 2: NUMBER OF STUDENTS WHO CHANGED A PARTICULAR BELIEF AND SOURCES OF CHANGE 


\begin{tabular}{|c|c|c|}
\hline $\begin{array}{l}\text { 25. It is difficult to construct a } \\
\text { good test. }\end{array}$ & S5, S7, S8 & Teaching techniques (3) \\
\hline $\begin{array}{l}\text { 26. It is necessary to correct } \\
\text { every mistake a student makes. }\end{array}$ & S6, S7, S8, S9, S10, S11 & $\begin{array}{l}\text { Teaching techniques (2) } \\
\text { Field work (2) } \\
\text { Teaching techniques and field } \\
\text { work (1) } \\
\text { Teaching techniques, field work } \\
\text { and Theories of language acquisi- } \\
\text { tion (1) }\end{array}$ \\
\hline $\begin{array}{l}\text { 27. The teacher should improve } \\
\text { his knowledge and skills con- } \\
\text { stantly. }\end{array}$ & Total: 1 & Teaching techniques (1) \\
\hline
\end{tabular}

TABLE 2: NUMBER OF STUDENTS WHO CHANGED A PARTICULAR BELIEF AND SOURCES OF CHANGE

As it became obvious from both the quantitative and qualitative data analysis that student teachers' beliefs were impacted by the courses they attended, the researchers wanted to find out which course was most impactful and what exactly the students learned from them. As can be seen from Table 3, the most memorable learning experience for the students from the two courses was that related to lesson planning, dealt with within the practical course (Teaching techniques). Of the 11 respondents, 10 reported that their beliefs about lesson planning changed, corroborating the finding obtained by the statistical analysis conducted for the purposes of this paper (see Section Results of questionnaires). Such a finding may be explained by students previously having not been thoroughly acquainted with the principles and practice of designing lesson plans, in which case they may have had only vague ideas, and not well-formed beliefs, about how these are created. Hence, the impact the course had on their beliefs regarding lesson planning was significantly different in two questions (see Section Results of questionnaires).

The results of the statistical analysis conducted (see Section Results of questionnaires) also show that the students' beliefs regarding the role of the course book in language teaching (Table 2, statement 4) and the ways to teach grammar (Table 2, statement 8) changed significantly. Interestingly, only one student (Table 2, S3) reported that one of the courses he attended impacted his belief pertaining to the course book as a teaching resource, even though the results for statement 4 presented in Table 2 reveal that five 
students reported that it was the Teaching Techniques course that altered this belief. Neither course seems to have had a great impact on students' beliefs regarding teaching grammar, as it is obvious from the results for statement 8 presented in Table 2 that all eight students whose beliefs regarding grammar changed reported field practice as the sole source of their altered views.

Regarding other effects from the courses that the students reported, i.e., changes in their beliefs about techniques for teaching language skills (S5), error correction (S7), or the student-teacher relationship (S10), these appear to be individual as there were not found to be statistically significant changes at the group level.

\begin{tabular}{|c|l|}
\hline STUDENT & \multicolumn{1}{|c|}{ EFFECTS OF COURSES } \\
\hline 1 & Lesson planning \\
\hline 2 & Lesson planning \\
\hline 3 & Lesson planning, the role of course book \\
\hline 4 & Lesson planning \\
\hline 5 & Lesson planning, techniques for teaching language skills \\
\hline 6 & Techniques for teaching language skills \\
\hline 7 & Lesson planning, error correction techniques \\
\hline 8 & Lesson planning \\
\hline 9 & Lesson planning \\
\hline 10 & Lesson planning, student-teacher relationship \\
\hline 11 & Lesson planning \\
\hline \hline
\end{tabular}

TABLE 3: REPORTED EFFECTS OF UNIVERSITY COURSES ON CHANGING BELIEFS

CONCLUSIONS
The results of the research this paper is based on undoubtedly indicate that student teachers' beliefs can change as a result of exposure to different teacher preparation programs, especially if those programs combine professional experience and specific coursework (Sheridan 2016, p. 14). The most effective factor in changing their beliefs is field work, closely followed by an experiential and reflective course that enables students to try out what they learn in theory, get and give feedback, observe practicing teachers, and attempt real classroom teaching. The least effective factor in changing students' entry beliefs seems to be a purely theoretical course, as it does not give students much chance to collaborate 
with peers, mentors, or teachers, or to get hands-on experience. Most of our respondents reported a number of factors influencing the changes in their beliefs, the most dominant being field work and the least dominant being the primarily theoretical course they attended.

Generally speaking, the results also show that all students' beliefs can be altered as not a single belief was found to have not changed for at least one student during the semester. This indicates that pedagogical beliefs related to all educational issues can be changed during a teacher preparation program. At the individual level, however, a detailed analysis reveals that different students report different variables that change their beliefs and some are found to remain unchanged at the end of the semester.

REFERENCES Bangou, F., Fleming, D., \& Goff-Kfouri, C. A. (2011). Pre-Service Teachers' Beliefs Related to English as a Second Language and English as a Foreign Language: Where is the Difference? Theory and Practice in Language Studies, 1 (9), 1031-1040.

Beijaard, D., Meijer, P. C., \& Verloop, N. (2004). Reconsidering Research on Teachers' Professional Identity. Teaching and Teacher Education, 20, 107-128.

Borg, M. (2005). A Case Study of the Development in Pedagogic Thinking of a Pre-Service Teacher. TESL-EJ, 9, 1-30.

Borg, S. (2006). Teacher Cognition and Language Education: Research and Practice. London: Continuum.

Borg, S. (2011). The Impact of In-Service Teacher Education on Language Teachers' Beliefs. System, 39, 370-380.

Busch, D. (2010). Pre-Service Teacher Beliefs about Language Learning: The Second Language Acquisition Course as an Agent for Change. Language Teaching Research, 14, 318-337.

Buchmann, M. (1987). Teaching Knowledge: The Lights That Teachers Live by. Oxford Review of Education, 13, 151-164.

Cabaroglu, N., \& Roberts, J. (2000). Development in Student Teachers' Preexisting Beliefs during a 1-Year PGCE Programme. System, 28, 387-402.

Clarke, M. (2008). Language Teacher Identities. Clevedon: Multilingual Matters. Clark-Goff, K. (2008). Exploring Change in Preservice Teachers' Beliefs about English Language Learning and Teaching. (Unpublished doctoral dissertation). A\&M University, Texas. Retrieved from http://oaktrust.library.tamu.edu/bitstream/handle/1969.1/ETD-TAMU-2705/CLARK-GOFF-DISSERTATION.pdf. 
Debreli, E. (2012). Change in Beliefs of Pre-Service Teachers about Teaching and Learning English as a Foreign Language throughout an Undergraduate Pre-Service Teacher Training Program. Procedia - Social and Behavioral Sciences, 46, 367-373.

Doyle, M. (1997). Beyond Life History as a Student: Preservice Teachers' Beliefs about Teaching and Learning. College Student Journal, 31 (4), 519-532.

Florio-Ruane, S., \& Lensmire, T. J. (1990). Transforming Future Teachers' Ideas about Writing Instruction. Journal of Curriculum Studies, 22, 277-289.

Glušac, T. (2016). Međusobno obučavanje kolega kao oblik usavršavanja profesora engleskog jezika [Peer Coaching as a Form of Professional Development for English Language Teachers]. Novi Sad: Filozofski fakultet.

Glušac, T., Milić, M., \& Pilipović, V. (2017). Analiza pedagoških uverenja nastavnika engleskog jezika u Srbiji [The Analysis of Pedagogical Beliefs of Serbian Teachers of English]. In: S. Gudurić \& B. Radić-Bojanić (Eds.), Languages and Cultures in Time and Space VI (429-449). Novi Sad: Faculty of Philosophy.

Graus J., \& Coppen P-A. (2015). Student Teacher Beliefs on Grammar Instruction. Language Teaching Research, 20 (5), 1-29.

Guskey, T. R. (1986). Staff Development and the Process of Teacher Change. Educational Researcher, 75 (5), 5-12.

Gutierrez Almarza, G. (1996). Student Foreign Language Teachers' Growth. In: M. Reynolds (Ed.), Knowledge Base for the Beginning Teacher (23-36). Oxford: Pergamon.

Hall, L. A. (2005). Teachers and Content Are Reading: Attitudes, Beliefs and Change. Teacher and Teacher Education, 2, 403-414.

Kagan, D. M. (1992). Professional Growth among Preservice and Beginning Teachers. Review of Educational Research, 62, 129-169.

Kier, M. W., \& Lee T. D. (2017). Exploring the Role of Identity in Elementary Preservice Teachers Who Plan to Specialize in Science Teaching. Teaching and Teacher Education, 61, 199-210.

Moscovici, S. (1984). The Phenomenon of Social Representations. In: R. Farr \& S. Moscovici (Eds.), Social Representations (3-70). Cambridge: Polity Press.

Pajares, F. (1992). Teachers' Beliefs and Educational Research: Cleaning up a Messy Construct. Review of Educational Research, 62 (3), 307-332.

Peacock, M. (2001). Pre-Service ESL teachers' Beliefs about Second Language Learning: A Longitudinal Study. System, 29, 177-195.

Pennington, M.C. \& Urmston, A. (1998). The Teaching Orientation of Graduating Students on a BA TESL Course in Hong Kong: A Comparison with First-Year Students. Hong Kong Journal of Applied Linguistics, 3, 17-46.

Phipps, S., \& Borg S. (2009). Exploring Tensions between Teachers' Grammar Teaching Beliefs and Practices. System, 37 (3), 380-390. 
Sheridan, L. (2016). Examining Changes in Pre-Service Teachers' Beliefs of Pedagogy. Australian Journal of Teacher Education, 41 (3), 1-20.

Urmston, A. (2003). Learning to Teach English in Hong Kong: The Opinions of Teachers in Training. Language and Education, 17, 112-137.

Valcke, M., Sang, G., Rots, I., \& Hermans, R. (2010). Taking Prospective Teachers' Beliefs into Account in Teacher Education. In: P. Peterson, E. Baker \& B. McGaw (Eds.), International Encyclopedia of Education (622-628). Oxford: Elsevier.

Wall, G. C. (2016). From Student to Teacher: Changes in Preservice Teacher Educational Beliefs throughout the Learning-to-Teach Journey. An International Journal of Teachers' Professional Development, 20, 364-379.

Williams, M., \& Burden, R. L. (1997). Psychology for Language Teachers: A Social Constructivist Approach. Cambridge: Cambridge University Press.

Wilson, S. M. (1990). The Secret Garden of Teacher Education. Phi Delta Kappan, 72, 204-209.

Yero, J. L. (2002). Teaching in Mind: How Teacher Thinking Shapes Education. Hamilton, MT: MindFlight Publishing.

ТАТЈАНА Љ. ГЛУШАЦ

ВЕСНА Б. ПИЛИПОВИЋ

УНИВЕРЗИТЕТ „УНИОН“ БЕОГРАД

ФАКУЛТЕТ ЗА ПРАВНЕ И ПОСЛОВНЕ СТУДИЈЕ „ДР ЛАЗАР ВРКАТИК “

ДЕПАРТМАН ЗА ЕНГЛЕСКИ ЈЕЗИК

РЕЗИМЕ

ПЕДАГОШКА УВЕРЕЊА СТУДЕНАТА ЕНГЛЕСКОГ ЈЕЗИКА: ПОДЛОЖНОСТ

ПРОМЕНИ И ИЗВОРИ ПРОМЕНА

Педагошка уверења представљају претпоставке о различитим елементима образовног процеса и стога утичу на целокупну педагошку активност наставника. Релевантна литература истиче да је неопходно што раније открити педагошка уверења студената који се припремају за наставнички позив, али даје контрадикторне доказе у вези са утицајем који програми за обуку будућих наставника имају на промену уверења студената који учествују у тим програмима. Циљ овог рада је да испита да ли се уверења студената могу променити као резултат њиховог похађања различитих курсева у оквиру којих се припремају за наставнички позив, као и која врста курса највише доприноси поменутој промени. За потребе овог рада спроведен је мешовити методолошки поступак (упитник и интервју) током летњег се- 
местра 2017. године. Узорак је чинило 11 студената мастерских студија са приватног факултета у србији, који су током поменутог семестра похађали укупно три курса у оквиру којих су се припремали за наставнички позив. Квантитативни део истраживања реализован је на почетку и на крају летњег семестра помоћу упитника са петостепеном Ликертовом скалом, а тако добијени резултати обрађени су помоћу статистичког пакета SPSS 15. Квалитативни део истраживања спроведен је путем полуструктуисаног интервјуа, а подаци добијени на тај начин обрађени су применом индуктивног приступа. Добијени резултати показују да постоји тек неколико статистички значајних промена уверења на нивоу групе, док подаци за сваког појединачног испитаника указују на низ веома значајних промена њихових педагошких уверења. Највећи утицај на промену постојећих уверења студената има пракса, потом теоријско-практични курс, док најмањи учинак на промену уверења има чисто теоријски курс.

КључнЕ РЕчИ: педагошка уверења студената; претходна уверења; промена уверења; енглески језик.

Овај чланак је објављен и дистрибуира се под лиценцом Creative Commons Ауторство-Некомерцијално Међународна 4.0 (СC BY-NC 4.0 | https://creativecommons.org/licenses/by-nc/4.0/).

This paper is published and distributed under the terms and conditions of the Creative Commons Attribution-NonCommercial International 4.0 licence (CC BY-NC 4.0 | https://creativecommons.org/licenses/by-nc/4.0/). 